\title{
The pathophysiology associated with primary (idiopathic) frozen shoulder: A systematic review
}

\author{
Victoria Ryan ${ }^{1,4}$, Hazel Brown², Catherine J. Minns Lowe ${ }^{3}$ and Jeremy S. Lewis $3,4^{*}$
}

\begin{abstract}
Background: Frozen shoulder is a common yet poorly understood musculoskeletal condition, which for many, is associated with substantial and protracted morbidity. Understanding the pathology associated with this condition may help to improve management. To date this has not been presented in a systematic fashion. As such, the aim of this review was to summarise the pathological changes associated with this primary frozen shoulder.

Methods: Databases: Medline, Embase, CINAHL, AMED, BNI and the Cochrane Library, were searched from inception to 2nd May, 2014. To be included participants must not have undergone any prior intervention. Two reviewers independently conducted the; searches, screening, data extraction and assessment of Risk of Bias using the Cochrane Risk of Bias Assessment Tool for non-Randomised Studies of Interventions (ACROBAT-NRSI). Only English language publications reporting findings in humans were included. The findings were summarised in narrative format.

Results: Thirteen observational studies (involving 417 shoulders) were included in the review. Eight studies reported magnetic resonance imaging or arthrography findings and 5 recorded histological findings. When reported mean ages of the participants ranged from 40.0 to 59.8 years. Duration of symptoms ranged from 0 to 30 months. The majority of studies $(n=7)$ were assessed to be of moderate risk of bias, two studies at high risk and the remaining four were rated as low risk of bias. Study characteristics were poorly reported and there was widespread variety observed between studies in respect of data collection methods and inclusion criteria employed. Pathological changes in the anterior shoulder joint capsule and related structures were commonly reported. Imaging identified pathological changes occurring in the coracohumeral ligament, axillary fold and rotator interval. Obliteration of the subcoracoid fat triangle also appeared to be pathognomonic. Histological studies were inconclusive but suggested that immune, inflammatory and fibrotic changes where associated with primary frozen shoulder.
\end{abstract}

Conclusions: This systematic review presents a summary of what is currently known about the tissue pathophysiology of primary frozen shoulder. Further studies that use standardised inclusion and exclusion criteria and investigate changes in naïve tissue at different stages of the condition are required.

Keywords: Frozen Shoulder, Adhesive capsulitis, Systematic review, Imaging, Histology

\footnotetext{
* Correspondence: jeremy.lewis@LondonShoulderClinic.com

${ }^{3}$ Department of Allied Health Professions and Midwifery, School of Health

and Social Work, University of Hertfordshire, Hatfield, UK

${ }^{4}$ Central London Community Healthcare NHS Trust, London, UK

Full list of author information is available at the end of the article
} 


\section{Background}

Although frozen shoulder is considered to be a common musculoskeletal condition, with reviews reporting up to $5.3 \%$ of the population being affected [1], definitive prevalence and incidence rates remain unknown [2]. The condition is associated with; (often severe) pain, sleep deprivation, anxiety, and disability that may be hugely disruptive and impacts on nearly every aspect of daily living [3]. The average duration of the condition is 30.1 months (range 1 to 3.5 years) [4] but it may be substantially longer $[5,6]$, and the burden placed upon individuals and health care services may therefore be considered substantial [7].

The term "frozen shoulder" was introduced in 1934 by Codman who described the disorder as "difficult to define, difficult to treat and difficult to explain" [8]; and in many respects this remains true today. Frozen Shoulder (FS) has been classified into primary and secondary conditions [9]. Primary FS (PFS) is characterised by an insidious onset of idiopathic origin whereas secondary FS is associated with a defined event, such as a known intrinsic (such as rotator cuff disease) or extrinsic (such as trauma) cause [10]. FS associated with medical conditions such as diabetes and thyroid disorders are subcategorised as secondary systemic frozen shoulder [11].

Symptoms associated with frozen shoulder include: localised pain, pain with movement, night pain (rendering the patient unable to sleep on the affected side), marked limitation of active and passive range of movement (particularly external rotation) and normal shoulder radiograph findings [8]. However, the absence of definitive diagnostic criteria imposes challenges for clinical diagnosis and management and research [12]. This diagnostic challenge is further complicated by the clinical overlap in signs and symptoms between frozen shoulder and other conditions, such as; rotator cuff tendinopathy, calcific tendonitis or early glenohumeral arthrosis $[13,14]$. A recent narrative review suggested thickening of the coracohumeral ligament (CHL), joint capsule and synovium to be diagnostic features for frozen shoulder [15]. However no systematic review has yet collated the data from imaging studies to specify the intra and peri-articular changes that are associated with the condition.

Historically, the pathology of FS has been attributed to structures such as the subacromial bursa and joint capsule $[16,17]$. As arthroscopic and microbiological techniques have advanced other structures have been associated with the pathogenesis of the condition: namely, the rotator interval (RI), long head of biceps (LHB) and the CHL [18]. Contemporary histological analyses have identified the presence of inflammatory markers within the asscoiated tissue [19]. Cytokines, such as Tumour Necrosis Factor (TNF) $\alpha$, Interleukin
(IL) $1 \alpha$ and $\beta$ and IL- 6 have also been identified [20]. In addition, studies have reported high numbers of fibroblasts and myofibroblasts, suggestive of a fibrotic process $[21,22]$. An immunological component has also been linked with frozen shoulder; such as the presence of Blymphocytes, mast cells and macrophages [23]. Such studies have led to the suggestion that FS may begin as an immunological response which escalates to an inflammatory synovitis, eventually leading to fibrosis of the capsule and that future research should focus on disease [15].

The purpose of this systematic review was to identify and synthesise the available evidence regarding the intra and peri-articular pathophysiology of primary frozen shoulder. A secondary aim was to identify deficits in our knowledge that may inform future research. The review was designed to include studies that had investigated the pathology, physiology, physiopathology, neurophysiology, histology, histocytochemistry, microbiology, immunochemistry or immunohistochemistry of the glenohumeral joint and its related structures in adults diagnosed with primary frozen shoulder.

\section{Methods}

This review is reported in accordance with the PRISMA statement for reporting systematic reviews [24].

\section{Searches}

Databases (Medline, Embase, CINAHL, AMED, BNI and the Cochrane Library) were searched from inception until 2nd May, 2014. Searches were performed independently by two researchers (HB and VR). The search strategy was developed using the Population and Intervention component of the PICO formula (Population, Intervention, Comparator and Outcome) [25]. Search terms related to patho-anatomical and pathophysiological changes associated with primary idiopathic frozen shoulder (Table 1). No language restrictions were applied and searches were limited to human studies. In addition to the formal data base searches a reference list search of included publications was also conducted.

\section{Eligibility criteria}

Studies were included if the participants were diagnosed as having PFS and had undergone combinations of imaging, histological or biochemical analysis of the glenohumeral joint. Studies were excluded if participants were diagnosed with any form of secondary frozen shoulder, such as diabetes, rotator cuff disease or trauma [12]. To reduce confounding the findings, studies were also excluded if participants had undergone previous interventions directly to the shoulder joint (and were termed non-naïve studies). This was because steroid injections may impact on the structure and biochemistry of the 
Table 1 MEDLINE search strategy used in the review

1 SHOULDER JOINT/ (13897)

2 SHOULDER/ (8870)

3 shoulder*ti,ab. (41413)

4 exp JOINT CAPSULE/ (25623)

5 BURSA, SYNOVIAL/ Or CARTILAGE, ARTICULAR/ (23509)

6 LIGAMENTS/ or LIGAMENTS, ARTICULAR/ (17025)

7 subacromial bursa.ti,ab. (207)

81 or 2 or 3 or 4 or 5 or 6 or 7 or 8 (107701)

9 ELBOW/ or KNEE/ or HIP/ or ELBOW JOINT/ or exp KNEE JOINT/ or HIP JOINT/ (89002)

108 not 9 (92176)

11 JOINT DISEASES/ or CONTRACTURE/ or exp BURSITIS/ (10137)

12 bursit*.ti,ab. (1880)

13 (adhesive and capsul*).ti,ab. (709)

14 (contracted and shoulder*).ti,ab. (79)

15 (stiff and shoulder*).ti,ab. (220)

16 (restricted and shoulder*).ti,ab. (443)

17 (("50" or fifty) and year and old and shoulder*).ti,ab. (142)

18 contracture*.ti,ab. (15710)

19 (capsular and adhes*).ti,ab. (533)

20 ARTHRALGIA/ (4808)

21 SHOULDER PAIN/ (2817)

22 PERIARTHRITIS/ (1087)

23 (frozen and shoulder*).ti,ab. (862)

2411 or 12 or 13 or 14 or 15 or 16 or 17 or 18 or 19 or 20 or 21 or 22 or 23 (31479)

25 SHOULDER/pa, ph, pp [Pathology, Physiology, Physiopathology] (2414)

26 SHOULDER JOINT/pa, ph, pp [Pathology, Physiology, Physiopathology] (6206)

27 PHYSIOLOGY/ Or NEUROPHYSIOLOGY/ (28421)

28 (pathophysiol* or patho-physiol* or physiopathol* or physio-pathol*).ti,ab. (152283)

29 physiology.ti,ab. (78959)

30 HISTOLOGY/ Or HISTOCYTOCHEMISTRY/ (74633)

31 (histol* or histop*).ti,ab. (520480)

32 MICROBIOLOGY/ (5837)

33 microbiolog*.ti,ab. (57683)

34 IMMUNOCHEMISTRY/ (9093)

35 IMMUNOHISTOCHEMISTRY/ (246272)

36 immunohistochem*.ti,ab. (236072)

3725 or 26 or 27 or 28 or 29 or 30 or 31 or 32 or 33 or 34 or 35 or $36(1197286)$

$38 \quad 10$ and 24 and 37 (1397)

39 limit 38 to humans (1336)

Database: Ovid MEDLINE(R) <1946 to 2nd May 2014> tissue $[15,26]$. Furthermore, arthrographic distension and capsular release are designed to disrupt the capsule [27] and manipulation under anaesthetic (MUA) may cause intra-articular damage to multiple structures [28]. Translation services were not available thus non English language studies, identified through the search, were subsequently excluded.

\section{Selection of studies}

Two reviewers (HB and VR) reviewed the articles for eligibility and inclusion with a third reviewer (JL) available in the event of consensus not being achieved. Article titles were used to identify relevant studies. Following this, eligibility was checked and recorded on a checklist designed for the review that incorporated PICO criteria. A data extraction form was developed for the review based upon the University of York, Centre for Reviews and Dissemination (2009) guidance [29].

\section{Data analyses}

Following data extraction, the study characteristics were tabulated and the studies synthesized. The variables synthesized in this review were reported findings from imaging studies of the shoulder joint and its related structures, as well as histological, neural and vascular findings. In addition, studies were assessed and their risk of bias appraised. Whether meta-analyses would be possible or appropriate was considered at this point.

\section{Risk of bias}

Although not always included in systematic reviews investigating pathophysiological mechanisms it was decided a priori to include an assessment of the risk of bias of the studies included in the current systematic review to enhance the validity of conclusion reached. The choice of a risk of bias tool for the review proved difficult as no one tool was perfectly compatible with this type of review. As the review question did not explore diagnostic accuracy the QUADAS-2 tool to evaluate the risk of bias and applicability of primary diagnostic accuracy studies was not considered appropriate. The ACROBAT-NRSI (A Cochrane Risk Of Bias Assessment Tool for Non-Randomized Studies of Interventions) is used when appraising the risk of bias in nonrandomized studies that compares the health effects of at least two interventions. Although the current review explored mechanisms rather than interventions, its domains appeared relevant and appropriate to the review and was chosen for use in the current review [30]. Studies were appraised to be at high, moderate or low risk of bias independently by two reviewers (HB and VR) with a third reviewer available in the event of any nonagreement (JL). 


\section{Results}

Three thousand five hundred fifty-one potentially relevant studies were identified in searches. Title, abstract and reference list screening identified 58 articles meeting the review criteria. Duplicates $(n=16)$ were removed and the full text of articles read. Thirteen studies met the inclusion criteria for the review and 29 studies were excluded (Table 2). A summary is provided in the PRISMA flow diagram (Fig. 1). The study characteristics are presented in Table 3.

All 13 included studies were observational in design. Nine studies included a control group [19, 31-38], four did not [14, 39-41]. Of those using a control group, four included patients with rotator cuff pathology [31, 32, 35, 37], three used asymptomatic controls [34, 36, 38] and two studies included patients with shoulder instability $[19,33]$. One study included two control groups [31], one with rotator cuff pathology and the other included people without symptoms. Study characteristics were generally poorly reported and there was widespread variation in diagnosis, methods of sample selection, timing of sample selection and presence of confounding variables such as use of oral medications. Eight out of 13 studies (62\%) based their inclusion criteria on the Codman classification [14, 31, 32, 34, 36, 38, 39, 42]. However, it was evident that there were substantial variations in the interpretation of this classification (Table 3).

The risk of bias data is presented in Table 4. The majority of studies $(n=7)$ were identified as having a moderate risk of bias, with two studies assessed of being at high risk of bias and the remaining four rated as low risk of bias. In general, sample sizes were small, ranging from one to seventy two (average $=28$ ) participants. All studies used convenience sampling. Despite eleven studies identifying potential confounding factors, only six [14, $31,33-35,38]$ reported how they had taken account of them in their study design and/or in their analysis. The risk of bias data and widespread variation between studies did not permit meta-analyses.

\section{Imaging findings}

Magnetic resonance imaging (MRI) findings were reported in five studies [14, 31, 32, 34, 38], with one study using Gadolinium enhancement [32] (Table 3). In descending order of frequency, findings included: a substantially thickened CHL [31,34, 38]; thickening of the joint capsule in the RI $[32,38]$ and axillary recess $[14,32]$; thickening of the synovial membrane in the RI [32] and axillary recess [14, 32]; partial or complete obliteration of the subcoracoid fat triangle [34, 38]; scarring and or thickening of the RI [14, 38]; fluid distension of the bursa within the superior subscapularis recess [31] and synovitis abnormalities around the LHB tendon [38].
Three studies used contrast enhancement arthrography, with two utilising magnetic resonance angiogram (MRA) [35, 36], and the third, radiology [40]. Arthrography findings were contradictory (Table 3 ). Song et al. [36] reported substantial thickening of the joint capsule in the axillary recess and the RI. Neviaser [40] reported reduced joint capacity secondary to thickening and contracture of the capsule (region unspecified), obliteration of the axillary fold and often complete or near complete abolition of the subscapularis bursa. In contrast, Manton et al. [35] reported a trend for greater capsular thickness in the axillary recess and at the humeral head and increased synovial thickness in the axillary recess in controls, when compared to patients with FS. They also reported that RI abnormalities were more common in control participants, concluding that there are no useful MRA signs of FS.

\section{Histology findings}

Extensive histological findings were reported (Table 3). Tissue samples demonstrated the following: a dense collagen matrix and high population of fibroblasts and contractile myofibroblasts [19, 21, 33, 41]; a fibrotic process limited to the anterior part of the capsule [41]; elevated levels of inflammatory cytokines in the SAB and anterior capsule [19] and the presence of mature and regenerating nerve fibres in the anterior capsule [37].

Five studies explored the histological and molecular changes associated with idiopathic FS (Table 5). When the study characteristics were reviewed limitations were evident. As previously identified, symptomology, demographics and the stage of the condition were poorly recorded. Secondly, there was substantial diversity between studies with regards to what was being measured. Furthermore, the techniques used to obtain the data also varied (Table 3).

\section{Neuronal and vascular findings}

$\mathrm{Xu}$ et al. [37] investigated neuronal changes within the condition. They reported elevated levels of several immunoreactive neuronal proteins (GAP43, PGP9.5 and P75) in the anterosuperior joint capsule. The distribution of these proteins was either close to small blood vessels or within fibroblastic tissue. Increased vascularity was a common feature identified in the histology studies; particularly located in the anterosuperior structures but absent in the inferior structures (with the exception of the $\mathrm{AF})$.

\section{Discussion}

\section{Summary of main findings}

This review identified that the anterior shoulder structures in primary frozen shoulder were the location of greatest pathological change and in the subsequent 
Table $\mathbf{2}$ List of excluded studies

\begin{tabular}{|c|c|c|c|c|c|c|c|c|c|}
\hline \multirow[t]{2}{*}{ Reference } & \multicolumn{5}{|c|}{ Secondary } & \multicolumn{3}{|l|}{ Injection } & Surgery \\
\hline & $\begin{array}{l}\text { Diabetes } \\
\text { mellitus }\end{array}$ & Trauma & $\begin{array}{l}\text { Rotator } \\
\text { cuff } \\
\text { disease }\end{array}$ & $\begin{array}{l}\text { Biceps } \\
\text { tendinopathy }\end{array}$ & $\begin{array}{l}\text { Cause } \\
\text { not } \\
\text { stated }\end{array}$ & Distension & $\begin{array}{l}\text { Corticosteroid } \\
\text { injection }\end{array}$ & $\begin{array}{l}\text { Hyaluronic } \\
\text { acid } \\
\text { injection }\end{array}$ & MUA Arthroscopy \\
\hline
\end{tabular}

Ahn, K., Kang, C., Oh, Y. \& Jeong, W.

x

(2012). Correlation between magnetic resonance imaging and clinical impairment in patients with adhesive capsulitis. Skeletal Radiology. 41(10), 1301-8. Bunker T. \& Anthony. P. (1995). The $\quad$ X

Dupuytren-like disease. Journal of Bone and Joint Surgery, 77B(5), 677-683.

Bunker, T., Reilly, J., Baird, K. \& Hamblen, D. (2000). Expression of growth factors, cytokines and matrix metalloproteinases in frozen shoulder. Journal of Bone and Joint Surger,. 82B(5), 768-773.

DePalma, A. (1952). Loss of scapulohumeral motion (frozen shoulder). Annals of Surgery, 135, 193-204.

Emig, E., Schweitzer, M., Karasick, D. \& Lubowitz, J. (1995). Adhesive capsulitis of the shoulder: MR diagnosis. American Journal of Roentgenology, 164(6), 1457-9.

Golkalp, G., Algin, O., Yildrim, N. \& Yazici, Z. (2011). Adhesive capsulitis: contrast enhanced shoulder MRI findings. Journal of Medical Imaging and Radiation Oncology, 55, 119-125.

Gondim Teixeira, P., Balaj, C., Chanson,

A., Lecocq, S., Louis, M. \& Blum, A. (2012). Adhesive capsulitis of the shoulder: value of inferior glenohumeral ligament signal changes on T2-weighted fat-saturated images. American Journal of Roentgenology, 198(6),589-596.

Hagiwara, Y., Ando, A., Onoda, Y., et al. (2012). Coexistence of fibrotic and chondrogenic process in the capsule of idiopathic frozen shoulders. Osteoarthritis and Cartilage, 20, 241-249.

Hand, G., Athanasou, N., Matthews, T. X \& Carr, A. (2007). The pathology of frozen shoulder. The Journal of Bone and Joint Surgery, 89, 928-932.

Jung, J., Jee, W., Chun, H. Kim, Y., Chung, Y. \& Kim, J. (2006). Adhesive capsulitis of the shoulder: evaluation with MR arthrography. European Radiology, 16(4), 791-796.

Kabbabe, B., Ramkumar, S. \& Richardson, M. (2010). Cytogenic analysis of the pathology of frozen shoulder. International Journal of Shoulder Surgery, 4(3), 75-78. 
Table 2 List of excluded studies (Continued)

Kanbe, K., Inoue, Y. \& Chen, Q. (2009).

Inducement of mitogen-activated

protein kinases in frozen shoulders.

Journal of Orthopaedic Science, 14, 56-61.

Kanbe, K., Inoue, K. \& Inoue, Y. (2008). X

Dynamic movement of the long head

of the biceps tendon in frozen

shoulders. Journal of orthopaedic

surgery, 16(3), 295-299.

Kim, Y., Kim, J., Lee, Y., Hong, O.

Kwon, H. \& Ji, J. (2013). Intercellular

adhesion molecule-1 (ICAM-1, CD54)

is increased in adhesive capsulitis. The

Journal of Bone and Joint Surgery,

95(4), e18.

Kim, K., Rhee, K. \& Shin, H. (2009).

Adhesive capsulitis of the shoulder

dimensions of the rotator interval

measured with magnetic resonance

arthrography. Journal of Shoulder \&

Elbow Surgery, 18(3), 437-42.

Lee, M., Ahn, J., Muhle, C., Kim, S.

Park, S., Kim, S. et al. (2003). Adhesive capsulitis of the shoulder diagnosis using magnetic resonance arthrography with arthroscopic findings as the standard. Journal of computer assisted tomography, 27, 901-906.

Lee, S., Park, J. \& Song, S. (2012).

Correlation of MR Arthrographic

findings and range of shoulder motions

in patients with frozen shoulder.

Musculoskeletal Imaging, 198, 173-179

Lefevre-Colau, M., Drape, J.. Fayad, F Rannou, F., Diche, T., Minvielle, F. et al. (2005). Magnetic resonance imaging of shoulders with idiopathic adhesive capsulitis: reliability of measures.

European Radiology, 15(12), 2415-22.

Loew, M., Heichel, T. \& Lehner, B.

(2005). Intraarticular lesions in primary frozen shoulder after manipulation under general anaesthetic. Journal of Shoulder and Elbow Surgery, 14(1), 16-21.

Nago, M., Mitsui, Y., Gotoh, M.

Nakama, K, Shirachi, I., Higuchi, F. et al. (2010). Hyaluronan modulates cell proliferation and mRNA expression of adhesion-related procollagens and cytokines in glenohumeral synovial/capsular fibroblasts in adhesive capsulitis Journal of Orthopaedic Research, 28(6), 726-731.

Ogilvie-Harris, D., Biggs, D., Fitsialos, D. \& MacKay, M. (1995). The resistant frozen shoulder Manipulation verses arthroscopic release. Clinical orthopaedics and related research, 319, 238-248.

Omari, A. \& Bunker, T. (2001). Open surgical release for frozen shoulder: Surgical findings and results of the release. Journal of Shoulder and Elbow Surgery, 10(4), 353-357. 
Table 2 List of excluded studies (Continued)

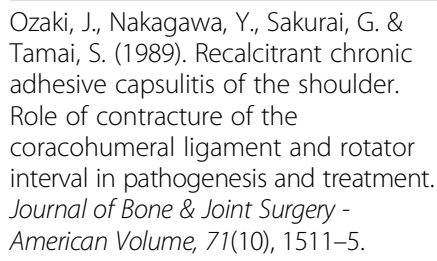

Rodeo, S., Hannafin, J., Tom, J.,

Warren, R. \& Wickiewicz, T. (1997). Immunolocalization of cytokines and their receptors in adhesive capsulitis of the shoulder. Journal of

Orthopaedic Research, 15(3), 427-436.

Shaikh, A. \& Sundaram, M. (2009).

Adhesive capsulitis demonstrated on

magnetic resonance imaging.

Orthopedics, 32(1), 61-62.

Tamai, K. \& Yamamoto, M. (1997).

Abnormal synovium in the frozen

shoulder: A preliminary report with

dynamic magnetic resonance

imaging. Journal of Shoulder and

Elbow Surgery, 6, 534-543.

Uitvlugt, G., Detrisac, D., Johnson, L., Austin, M. \& Johnson, C. (1993)

Arthroscopic observations before and after manipulation of frozen shoulder.

Arthroscopy, 9(2),181-5.

Wiley, A. (1991). Arthroscopic

appearance of frozen shoulder.

Arthroscopy, 7(2), 138-143. $x$

Articles that were excluded from the study are listed above. The reasons for exclusion are marked in the relevant column

clinical features of the disease, namely a loss of external rotation of the shoulder. The limited number of studies conducting histological analyses did not permit definitive conclusions pertaining to histological changes associated with PFS, however, and in line with previously published research, immune, inflammatory and fibrosis appear to play a role in the pathological process. The extent to which each component contributes and the variance associated with this cannot as yet be determined.

\section{Clinical inclusion criteria}

The review identified substantial variations in interpretation of the Codman classification. Future research must clearly detail defined and standardised diagnostic guidelines, to allow for more accurate and definitive comparisons between findings in studies.

\section{Imaging}

Imaging investigations varied substantially across the included trials and are a potential reason for the variations in findings. Three studies used arthrography, with two using direct arthrography, where contrast material was injected directly into the joint $[35,40]$. The basis for this is to permit a more precise visualisation of the intraarticular structures [43]. The contrast material was injected until the capsule distended which occurred at approximately $12-14 \mathrm{ml}$ of fluid [44]. Neviaser [17] reported that normal shoulder joint capacity is between $28-35 \mathrm{ml}$, often reducing to $5-10 \mathrm{ml}$ in cases of FS. Manton et al. [35] reported a tolerance of less than $10 \mathrm{ml}$ in all nine people with FS. Although the significance of reduced joint capacity in the diagnosis of FS remains uncertain [18, 45-47], the effect of capsular distension when introducing the contrast material may have confounded the published findings relating to the capsule and synovium [35, 47]. Song et al. [36] utilised indirect MRA, where contrast was injected intravenously into an antecubital vein. Indirect MRA requires exercising the joint for 10 to $15 \mathrm{~min}$ pre-imaging to increase vascular perfusion to improve flow into the joint [48], and again the influence of this activity on the reported findings is unknown. 

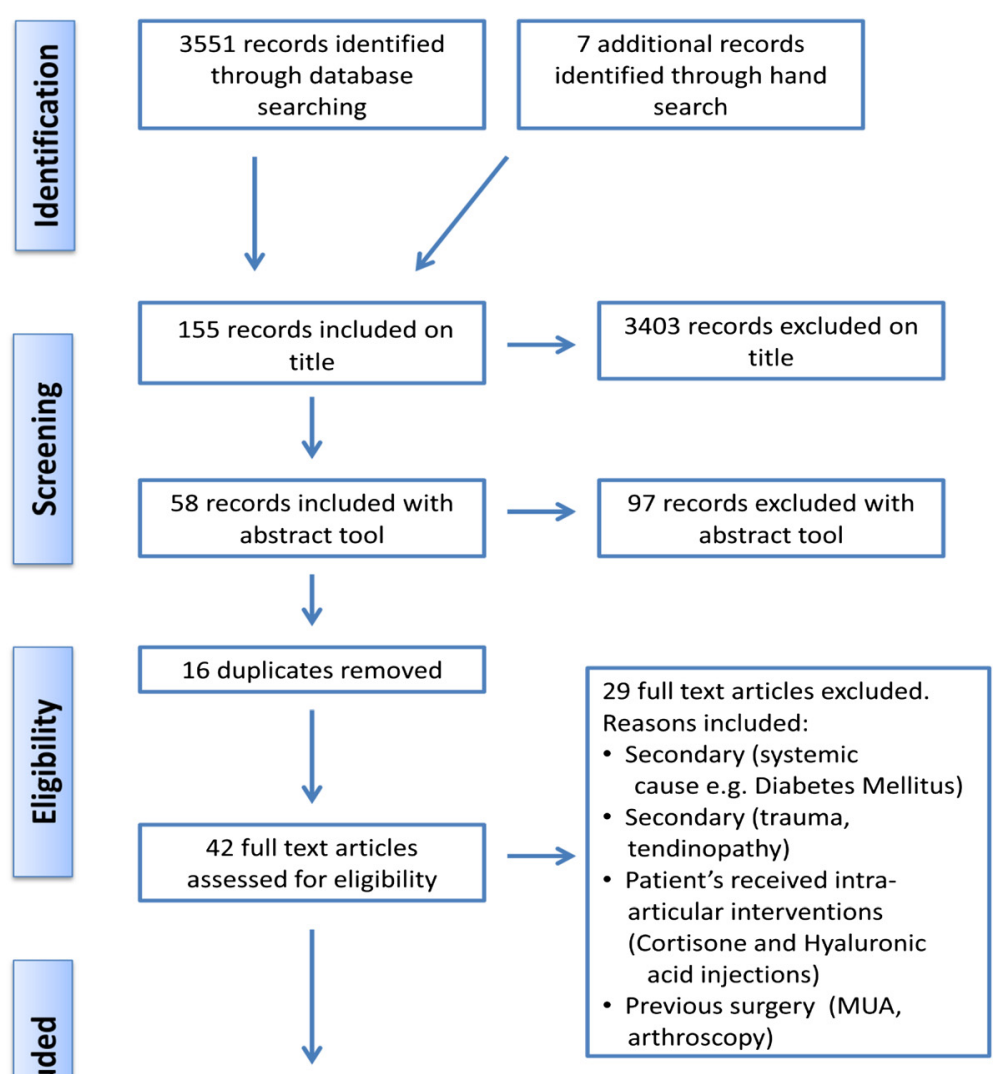

13 studies included in qualitative synthesis

Fig. 1 Systematic review protocol

There is no definitive guidance as to which imaging modality demonstrates greater diagnostic value in FS, and the heterogeneity of techniques used, and their associated potential confounding factors, limits deriving definitive conclusions relating to the articular and peri-articular changes associated with FS.

\section{Histology}

Symptomology, demographics and disease stage were poorly reported in the studies included in this review. The widespread diversity between studies with regards to what was being measured and how data was collected made comparison and synthesis of findings difficult. The main findings with respect to pathology identified in this review are presented in Tables 5 and 6 and are summarised below.

\section{Fibrosis and contracture}

Bunker [39] and Uhthoff and Boileau [41] used immunocytochemistry (ICC) and immunohistochemistry (IHC) to review matrix components. Both reported fibroblastic proliferation in the superior capsule and the RI. This is consistent with the imaging findings and with previous histological studies $[49,50]$. Vimentin is a cytocontractile protein and its presence may be assessed during ICC. Bunker [39] reported that vimentin was strongly expressed and confirmed that the cells were fibroblasts. In addition, when exposed to a smooth-muscle actin, many of the fibroblasts displayed a differentiation into a myofibroblastic phenotype. The myofibroblast, or contractile fibroblast, is the pathognomonic cell of contractile scar tissue and is found in Dupuytren's and the other fibromatoses [51]. Kilian et al. [33] used reverse transcription polymerase chain reaction (RTPCR) to study the mRNA (messenger RNA) transcription rates in the fibrosing stage of FS. They reported decreased levels of fibroblast like cells and $\alpha 1$ (III) chains which was indicative of a low number of myofibroblasts. The differing results may be due to samples being acquired at different stages of disease process; Bunker [39] did not supply information regarding stage of the condition or duration of symptoms since onset so comparison of results is challenging. Discrepancies in data may also relate to the way in which the tissue samples were managed. RTPCR 
Table 3 Characteristics of studies included in the review

\begin{tabular}{|c|c|c|c|c|c|}
\hline $\begin{array}{l}\text { Authors, date } \\
\text { and country of }\end{array}$ & Sample size and selection & $\begin{array}{l}\text { Inclusion and exclusion } \\
\text { criteria }\end{array}$ & $\begin{array}{l}\text { Technique used to } \\
\text { gain data }\end{array}$ & $\begin{array}{l}\text { Co-morbidities, previous } \\
\text { management, naïve tissue }\end{array}$ & Findings \\
\hline $\begin{array}{l}\text { Bunker, T. [39] } \\
\text { United Kingdom }\end{array}$ & $\begin{array}{l}\text { Sample: } N=35 \text {. Convenience } \\
\text { sample. Gender, age, symptom } \\
\text { duration and stage of frozen } \\
\text { shoulder not reported } \\
\text { Control: Nil }\end{array}$ & $\begin{array}{l}\text { Inclusion:“... fitted the criteria for primary } \\
\text { frozen shoulder" } \\
\text { Exclusion: Not reported }\end{array}$ & $\begin{array}{l}\text { Arthroscopy } \\
+ \text { Open release }\end{array}$ & $\begin{array}{l}\text { Co-morbidities, previous } \\
\text { management and } \\
\text { conservative treatment: } \\
\text { Not reported. } \\
\text { Tissue extracted from } \\
\text { patients who failed to } \\
\text { manipulate. } \\
\text { Naïve tissue: No }\end{array}$ & $\begin{array}{l}\text { Appearance: Consistent } \\
\text { abnormality of the subscapularis } \\
\text { bursa. Abnormal villous fronding } \\
\text { (large, finely divided expansion) } \\
\text { of the synovium. Nodular } \\
\text { appearance of the synovium. } \\
\text { Histology: Tissue consisted of } \\
\text { nodules and laminae of dense } \\
\text { collagen (mature' type III). } \\
\text { Nodules consisted of a collagen } \\
\text { matrix containing fibroblasts } \\
\text { arranged alongside layers or } \\
\text { bundles of dense collagen. The } \\
\text { cell population was moderate to } \\
\text { high. Increased vascularity (high } \\
\text { or moderate) in seven cases. } \\
\text { Immunocytochemistry; Vimentin } \\
\text { (a cytocontractile protein) was } \\
\text { strongly expressed. } \\
\text { Myofibroblasts present. Scanty } \\
\text { Leukocytes and macrophages } \\
\text { (white blood cells). Synovium: } \\
\text { (where present) entirely normal } \\
\text { or showed minimal papillary } \\
\text { infoldings without increased } \\
\text { cell production. }\end{array}$ \\
\hline $\begin{array}{l}\text { Carbone et al. } \\
\text { [31] } \\
\text { Italy }\end{array}$ & $\begin{array}{l}\text { Sample: } N=50 . \text { Convenience } \\
\text { sample. Gender not reported. } \\
\text { Mean age = 57.9 years }(S D=9) \\
\text { Symptom duration: Greater } \\
\text { than } 6 \text { weeks. Stage: "In the } \\
\text { freezing stage" } \\
\text { Control: } N=65 \\
\text { RC tear } N=50\end{array}$ & $\begin{array}{l}\text { Inclusion: Painful stiff shoulder ( } 6 \text { weeks), } \\
\text { severe pain effecting ADL, specific clinical } \\
\text { sign of FS, night pain, painful restriction of } \\
\text { active \& passive elevation to }<100^{\circ} \& \geq 50 \% \\
\text { restriction of external rotation. Exclusion: } \\
\text { age }<40 \text { or }>70 \text { year, wider tear than } \\
\text { short-wide RC tear and with subscapularis } \\
\text { tear, massive fluid distension of S-A space, } \\
\text { concomitant RC tear \& FS (full passive ROM), } \\
\text { previous treatment/ trauma shoulder } \\
\text { girdle/ spine. }\end{array}$ & MRI & $\begin{array}{l}\text { Co morbidities: Not } \\
\text { reported } \\
\text { Previous management: } \\
\text { Patients excluded if they } \\
\text { had received treatment } \\
\text { for shoulder pain- } \\
\text { including oral pain relief. } \\
\text { Naive tissue: Yes }\end{array}$ & $\begin{array}{l}\text { Appearance: High intensity signal } \\
\text { within the superior subscapularis } \\
\text { recess, consistent with fluid } \\
\text { distension of the bursa, found in } \\
89.95 \% \text { of FS patients. The bursa } \\
\text { fluid distension was over, in front } \\
\text { of and under the coracoid process. }\end{array}$ \\
\hline $\begin{array}{l}\text { Carrillon et al. } \\
{[32]} \\
\text { France }\end{array}$ & $\begin{array}{l}\text { Sample: } N=25 \text {. Convenience } \\
\text { sample. } M: F=3: 22 \text {. Mean } \\
\text { age }=51 \text { year } \\
\text { Symptom duration: } 2-10 \\
\text { months (mean }=6 \text { months. } \\
\text { Stage: Not reported } \\
\text { Control: } \\
\text { RC tear } N=15\end{array}$ & $\begin{array}{l}\text { Inclusion: clinical criteria for FS defined by } \\
\text { Codman \& Lundberg [9]; Gradually } \\
\text { increasing shoulder pain, most severe at } \\
\text { rest, } \geq 1 \text { month's duration, range of anterior } \\
\text { elevation of the shoulder no greater than } \\
135^{\circ} \text {; range of external rotation no }>20^{\circ} \text { and } \\
\text { normal GHJ X-ray (no joint space loss, osteo } \\
\text { phytes, or notches). Exclusion: Not reported. }\end{array}$ & $\begin{array}{l}\text { MRI } \\
\text { (Gadolinium } \\
\text { enhancement) }\end{array}$ & $\begin{array}{l}\text { Co morbidities and } \\
\text { previous management: } \\
\text { Not reported. } \\
\text { Naive tissue: Unknown }\end{array}$ & $\begin{array}{l}\text { Appearance: MRI: Thickening \& } \\
\text { postgadolinium enhancement } \\
\text { (signs of inflammation) of joint } \\
\text { capsule and synovial membrane } \\
(n=25) \text {, RI ( } n=25) \& \text { axillary recess } \\
(n=22) \text {. No posterior enhancement } \\
\text { (signs of inflammation) noted. } \\
\text { Postgadolinium enhancement seen } \\
\text { in the subacromial bursa ( } n=18) \text {, } \\
\text { supraspinatus \& infraspinatus } \\
\text { tendons }(n=9) \text { and ACJ }\end{array}$ \\
\hline
\end{tabular}

clusion: Painful stiff shoulder (6 weeks), severe pain effecting $A D L$, specific clinica , massive ROM), girdle/ spine.

(nclusion: clinical criteria for FS defined by Codman \& Lundberg [9]; Gradually

normal GHJ X-ray (no joint space loss, osteo 
Table 3 Characteristics of studies included in the review (Continued)

Kilian et al. [33] Sample: $N=6$. Convenience

Germany sample. Gender, mean age,

symptom duration not reported.

Stage: "Stage II" (Neviaser classification)

Control:

Shoulder Instability

$N=6$

Dupytrens $N=6$

Lho et al. [19] South Korea

Sample: $N=14$. Convenience sample. Gender, age, symptom duration and stage of frozen shoulder not reported

Control:

Shoulder Instability

$N=7$
Not reported

$+2$

Inclusion: Global restriction shoulder PROM.

Arthroscopic confirmation of of hypervascular synovitis\& thickened RI \&capsule. MRI

confirmed no pathology in Rl, labrum, LHB or

ACJ. Exclusion: Not reported
Arthroscopy

Co morbidities: Not reported

Previous management

Not reported.

Naive tissue: Unknown

ren

$n=17)$. Normal tendons of subscapularis and LHB in all patients $(n=25)$. Arthroscopy $(n=2)$ : Major hemorrhagic thickening of the capsule and synovium at the anterior and inferior part of the joint.

Histology: Quantitative Reverse Transcription Polymerase Chain Reaction (Q RT-PCR) Used for quantification of DNA sequences: A significant increase $(P<0.05)$ of a1 $(I)$ mRNA chains in FS. The quantity of a2(I) mRNA chains between FS, Dupuytren and normal capsular tissue showed no difference. The a1(III) mRNA transcription rate was similar in FS, Dupuytren and normal capsular tissue capsule. Immunohistochemistry: Decreased numbers of fibroblast-like cells with intracellular procollagen I staining recognisable in FS. Wen staining recognisable in FS. Weak staining of collagen I in FS and Dupuytren's tissue when compared to normal capsular tissue. Collagen II staining revealed a corresponding
distribution pattern in all 3 groups.

Histology: Elevated IL-1a (Interleukin 1

Co morbidities, previous management: Not reported

Naive tissue: No alpha cytokine) in RI capsule $(1.5+/-0.15, P<0.05)$ and $S A B$ $(2.3+/-0.24, P<0.05)$, compared to control gp $(1.0+/-0.01$ in joint capsule \& $2.0+/-0.06$ in SAB). Elevated IL-1 $\beta$ (interleukin 1 beta cytokine) in $\mathrm{Rl}$ capsule only

$(4.3+/-0.3, P<0.05)$, compared to control gp (3.1+/- 0.2). Stimulated levels of Tumor necrosis factor alpha cytokine (TNF- $a$ ) found in Rl capsule $(3.1+/-0.35, P<0.05) \&$ SAB $(3.5+/-0.41, P<0.01)$. Elevated levels of IL-6 (Interleukin 6 cytokine) in $S A B$ only $(2.2+/-0.3, P<0.01)$. Cycloogenase COX-1 (enzyme) was increased in the RI capsule only $(4.0+/-0.14, P<0.05)$. Cycloogenase COX-2 (enzyme) was

increased in the Rl capsule $(5.0+/-$ $0.15, P<0.05)$ and $S A B(6.9+/-0.94$ 
Table 3 Characteristics of studies included in the review (Continued)

$\begin{array}{ll}\text { Li et al. [34] } & \text { Sample: } N=72 . \mathrm{M}: F=22: 50 . \\ \text { China } & \text { Convenience sample. Mean } \\ & \text { age }=53.5 \text { years } \\ & \text { Symptom duration: } 15 \\ & \text { weeks }-18 \text { months } \\ & \text { (mean }=9.1 \text { months). } \\ & \text { Stage: Not reported. } \\ & \text { Control: } N=120\end{array}$

Manton et al. Sample: $N=9 \cdot M: F=7: 2$.

[35] Convenience (retrospective)

United States of sampling

America $\quad$ Mean age $=40$ year

Symptom duration and stage:

Not reported

Control:

Suspected RC or labral

pathology $N=19$

Neviaser, J. [40] Sample: $N=53$ Case series

United States of (1 case study). Gender, age

America symptom duration and
stage of frozen shoulder not reported

Control: Nil
Inclusion: "Clinical evidence of FS". Insidious onset pain \& dysfunction. Clinical criteria; increasing pain \&stiffness $>15$ weeks, most for 2 or more planes of movement. Exclus Previous trama ox shoulder surgt. Exclusion: RC tear, Calcium deposit on radiography, rheumatoid Arthritis, osteoarthritis, diabetes mellitus, thyroid/heart/ pulmonary/cervical disease, stroke.

Inclusion: Arthrographic diagnosis of $\geq 2$ of: Joint volume $<10 \mathrm{ml}$, poor /absent filling of axillary recess of the joint or biceps tendon sheath, irregularity of capsule insertion, pain after injection of $<10 \mathrm{ml}$ of contrast material, or extravasation of contrast material prior to injection of $10 \mathrm{ml}$ or more. Exclusion: Not reported

(Intra-articular Diodrast) Naive tissue: Unknown medical treatment
Co morbidities and

previous management:

Not reported

$P<0.05$ ) (but not in controls). TNF- $a$ and IL-6 were increased in joint fluid: TNF-a level higher in FS (16.0 +/$4.04 \mathrm{pg} / \mathrm{mL}$ (picograms per millilitre) than controls $(10.0+/-1.76 \mathrm{pg} / \mathrm{mL})$ $(P<0.05)$. Increased production of IL-6 in FS (21.8 +/- $4.63 \mathrm{pg} / \mathrm{mL})$ compared to controls $(3.7+/-$ $0.42 \mathrm{pg} / \mathrm{mL})(P<0.05)$.

Excluded. Appearance: Findings in the FS group, but not in control group:1. management: including antiinflammatory physiotherapy followed up for 24 months. Naive tissue: No

Co morbidities: Not reported.

Previous management:

No distention or anti-

inflammatory injection Naive tissue: No High-signal intensity soft tissue in the rotator cuff interval. 2. A thickened inferior glenohumera ligament (axillary recess).3. A low-signal intensity thickened $\mathrm{CHL}$. The $\mathrm{CHL}$ was not visualised in 10 out of 120 shoulders in the control group (8.3\%), and 15 out of 72 shoulders in the frozen shoulder group $(20.8 \%)(P<0.05)$. The CHL thickness in FS (3.99+/$1.68 \mathrm{~mm}$ ) was significantly $>$ control group $(3.08+/-1.32 \mathrm{~mm}),(P<0.001)$.

Appearance: No SD in amount of fluid in the biceps tendon sheath $(P=0.45)$ or the axillary recess $(P=0.37)$ between FS and controls. No corrugation of the synovium in FS, (In controls $n=7)$. No abnormalities of the rotator interval capsule in FS (In controls $n=7)$. The average thickness of the synovium and capsule at the axillary recess was $4.1 \mathrm{~mm}(\mathrm{FS})$ and $5.1 \mathrm{~mm}$ (controls) $(P=0.11$ ) The mean thickness of the capsule at the humeral head was $3.0 \mathrm{~mm}$ (FS) and $4.0 \mathrm{~mm}$ (controls) $(P=0.07)$

Appearance: Thickening and contracture of capsule with resultant decrease injoint capacity and adherence of the reflected fold causing obliteration of the dependent axillary fold. 42/53 patients had decreased joint capacity, obliteration of the axillary fold and frequently a complete/ almost complete 
Sofka et al. [14] Sample: $N=47 \mathrm{M}: F=13: 33$.

United States of Convenience sample

America Mean age $=53$ years Symptom duration and clinical staging: Stage 1:(0-3 months) $n=8$ Stage 2:(3-9 months) $n=23$ Stage 3:(9-15 months) $n=8$ Stage 4:(15-24 months) $n=8$ Control: $\mathrm{Ni}$
Inclusion:".....either the presumptive clinical diagnosis of FS or MRI findings suggestive of FS". Exclusion: Not reported

MRI

Co-morbidities and

previous management:

Not reported

Naive tissue: Unknown

absence of the subscapularis

bursa.

In every case there was In some instances the subscapularis bursa instances th the visualised. The biceps sheath was outlined in the majority of pts.

Only $18 \%$ of the shoulders with

visualisation of the biceps sheath

by arthrogram.

Appearance: Thickening of the axillary pouch ranged from 2-13 $\mathrm{mm}$ (average $=7 \mathrm{~mm}$ ). All subjects demonstrated RI scarring, (mild $n=16$, moderate $n=26$, severe $=$ $h=5)$. No SD between the degree of scarring between gps. Analysis of signal intensity of the capsule included $n=5$ with isointensity (the same intensity), 13 with

hypointensity, and 29 with hyporintensity relative to the normal signal of shoulder capsule. Capsular and synovial thickening (in the axillary pouch) demonstrated the most correlation with clinical stage of FS with a mean axillary pouch thickness for; stage 2 $(7.5 \mathrm{~mm})$, stage $1(4.1 \mathrm{~mm})$ stage $3(5.5 \mathrm{~mm})$ and stage 4 $(4.1 \mathrm{~mm})(P<0.05)$. No SD for values for stages 1,3 , and 4 when values for stages 1, 3, and 4 when compared to each other. Evaluation
of capsular signal was significant $(P=0.02)$, with hyperintense signal correlating with stage 2 .

Indirect MRA (Intra-venous Gadobutrol)

shousion. Clinical Diagnosis. painful shoulder for $\geq 4$ weeks, severe shoulder pain affecting $A D L /$ work, night pain, painfu restriction of active and passive elevation to $<100^{\circ}, 50 \%$ restriction of external rotation normal radiologic appearance, no secondary causes. Exclusion: RC tear, calcium deposition on radiograph. Bony abnormalities, such as \# of clavicle/ greater tuberosity of the humerus and bony Bankart lesion, shoulder surgery, or $>$ than specified ROM.
Co-morbidities and previous management Not reported.

Naive tissue: Unknown
Stage: Not reported
Appearance: FS patients had a significantly thicker joint capsule $(5.9+/-1.7)$ in the axillary recess and a significantly thicker enhancing portion $(6.5+/-2.5)$ of the axillary recess and of the $\mathrm{RI}(8.3+/-3.4)$ than control gp $(4.2+/-1.7$; $2.1+/-3.0 ; 3.0+/-3.6)(P<0.001)$ 5 pts with FS $(14 \%)$ and 7 controls $(16 \%)$ had subacromial bursitis $(P=1.0) .3$ pts with FS (9\%) and 7 controls (16\%) had OA of the ACJ $(P=0.5)$. No glenohumera 
Table 3 Characteristics of studies included in the review (Continued)

\begin{tabular}{|c|c|c|c|c|}
\hline $\begin{array}{l}\text { Uhthoff \& } \\
\text { Boileau [41] } \\
\text { France }\end{array}$ & $\begin{array}{l}\text { Sample: } N=4 . M ; F=0: 4 . \\
\text { Convenience sample. } \\
\text { Mean age = } 60 \text { year } \\
\text { Symptom duration: } 12 \text { months. } \\
\text { Stage: Not reported }\end{array}$ & Not reported & Arthroscopy & $\begin{array}{l}\text { Dupuytren's }(n=1) \\
\text { Previous managemen } \\
\text { Not reported } \\
\text { Naive tissue: Unknowr }\end{array}$ \\
\hline
\end{tabular}

joint effusion was observed in 29 of 35 patients with FS (83\%).

Appearance: Marked synovial

reaction of the $\mathrm{GHJ}$.

Histology: Little difference in

histological findings in synovial

tissue \& the extracellular matrix of

the posterior \& anterior structures.

Site of biopsy;(1) synovial tissue \& capsule from the posterosuperior

part of the joint $(n=4)$; (2) synovial

tissue and capsule at the Rl

$(n=4)$; (3) tissue from the $\mathrm{CHL}$

$(n=4)$; (4) synovial tissue and

capsule from the axillary fold

$(n=2)$; and (5) synovial tissue

and inferior capsule in contact

with the axillary nerve $(n=1)$.

Vimentin (a cytocontractile

protein) expression in synovial

at the level of the posterosuperior

site and the RI. Vimentin was

strongly expressed in cells and

extracellular matrix of the capsule

at the $\mathrm{Rl}$, the $\mathrm{CHL}$, and the

axillary fold.

No expression for vimentin

was detected in cells or in the

extracellular matrix from

posterosuperior capsule specimens.

Desmin not expressed in any

section. A marked synovial

vascular reaction accompanied

by formation of villi was found

at all sites (intensity varied among

different locations). Presence of

fibroplasia was evident at all

surgically released sites, and areas

of spatially nonaligned type III

collagen, containing an increased

number of fibroblasts, were

separated by strands of spatially

aligned type I collagen containing the typical fibrocytes in nearly

normal numbers. The simultaneous presence of types I and III collagen was similar at all released sites with the exception of the inferior capsule in which little type III collagen was found. Signs of 
Table 3 Characteristics of studies included in the review (Continued)

$\begin{array}{lll}\text { Xu et al. [37] } & \text { Sample: } N=8 . M: F=5: 3 . & \text { Inclusion: Pain at night and rest. } \\ \text { Australia } & \text { Sample: Unclear. Mean } & \text { Radiograph = normal. Decreased ROM } \\ & \text { age }=58 \text { years } & \text { under anaesthetic. Evidence of synovial } \\ & \text { Symptom duration: 4-9 } & \text { fibroblastic proliferation \& associated } \\ & \text { months (mean }=6.3 \text { months). } & \text { fibrosis on histological examination of } \\ & \text { Stage: Not reported } & \text { biopsy samples. Exclusion: Previous } \\ \text { Control: } & \text { surgery, radiographic signs of shoulder } \\ & \text { RC pathology } N=10 & \text { girdle \#, Rheumatoid Arthritis, pts with } \\ & \text { FS \& RC tear at same time. }\end{array}$

inflammation or perivascular infiltration were not detected in any section.

Arthroscopy

Co morbidities and previous management: Not reported.

Naive tissue: Unknown

Appearance: Capsular tissue from

FS patients was thickened and

hyperaemic. Subsynovial

hypercellularity was noted, with

fibroblastic proliferation and

associated variable, focally

prominent collagen production

and fibrosis. Associated prominent

small vascular channels and vascular

congestion was seen. [In RC tissue,

plump connective tissue cells in a

loose fibrous stroma were noted

vascular proliferation was not present

and fibroblastic proliferation with

fibrosis was not evident.]. PGP9.5 (a

pan-neuronal marker) and GAP43

(a neuronal membrane protein, nerve

marker) immunoreactions: The

immunoreactivity pattern of

distribution of the nerve markers

PGP9.5 and GAP43 was similar in

capsular tissue from FS and from

controls- Both were mainly seen

in the subsynovial tissue adjacent

to blood vessels. In the FS tissue,

PGP9.5 nerve fibres were often

observed close to small blood

vessels and within the fibroblastic

tissue. The expression of PGP9.5 and

GAP43 was significantly higher in FS

samples $(2.8+/-0.2$ and $2.4+/-0.4$

per field) than in rotator cuff tear

samples $(1.6+/-0.6$ and $1.3+/$ -

0.4 per field, $P<0.05$ ). CD34 (a blood

vessel marker) immunoreactions:

CD34 was strongly expressed in the

capsular tissue in $6 \mathrm{FS}$ patients (75 \%) but in only 1 rotator cuff tear patient

$(10 \%)$, supporting increased

vascularity in the FS samples.

Increased subsynovial vascularity and

increased numbers of plump

fibroblasts were observed in FS

compared with RC patients. Vascular

proliferation and congestion in the

subsynovial fibrous tissue was seen

only in FS.P75 (a nerve growth factor

(NGF) receptor - neurotrophin 


$\begin{array}{ll}\text { Zhao et al. [38] } & \text { Sample: } N=60 \mathrm{M}: F=24: 36 . \\ & \text { Sample: Unclear. Mean } \\ \text { China } & \text { age }=50.2 \text { years } \\ & \text { Symptom duration: } 15 \\ & \text { weeks - } 30 \text { months } \\ & \text { (mean = } 12 \text { months) } \\ & \text { Stage: "Patients were classified } \\ & \text { into early or late stage" } \\ & \text { Further details unclear. } \\ & \text { Control: } N=60\end{array}$

Inclusion: Clinically diagnosed with FS, insidious onset of pain and dysfunction. Clinical criteria: increasing pain and stiffness for $>15$ weeks, most severe at rest, with restriction of PROM greater than $30^{\circ}$ in two or more planes of movement. Exclusion: Previous surgery or trauma. Neurological disorder involving the upper limbs. Clinical history and clinical examination compatible with RC tear. Presence of calcium deposition on Presence of calcium deposition on
radiographic evaluation, Rheumatoid arthritis, Osteoarthritis. receptor) immunoreactions:P75 was expressed in vascular adventitia (the outer most connective tissue) and nerve fibres around blood vessels and was frequently seen in the subsynovial tissue. Although not everywhere, increased expression of P75 was observed in the FS samples compared with RC patients. Moderate to strong staining for P75 antibody was noted in the capsular tissue in $100 \%$ of FS but only in $30 \%$ of RC samples.

Appearance: FS pts had a significantly thicker $\mathrm{CHL}$

(4.21 mm +/- 0.97) than

control subjects $(2.12 \mathrm{~mm}+/$ $0.84, P<0.001)$. Mean thicknes of the articular capsule at the RC interval $>$ in FS pts (7.20 $\mathrm{mm}+/-2.13)$ than in controls (4.43 mm +/- 1.16, $P<0.05)$. Partial or complete obliteration of the subcoracoid fat triangle ("subcoracoid triangle sign") was significantly more frequent in FS pts compared with control subjects (partial obliteration, 22 vs. 2 cases (73\% vs. $13 \%$ ): complete obliteration, $8 \mathrm{vs}$. 1 cases ( $26 \%$ vs. $1.6 \%$ ) $P<0.001$. Synovitis-like abnormalities around the long biceps tendon around the long biceps tendon
were also markedly more frequent were also markedly more frequent
in patients than in control subjects in patients than in control subject
$(18$ vs. 2 cases $(60 \%$ vs. $6 \%)$, $P<0.05$. Patients were not significantly different from control subjects with regard to synovitis-like abnormalities at the articular surface of the subscapularis tendon or in the subscapularis tendon or in the
supraspinatus muscle tendon. 
Table 4 Risk of bias results for the studies included in the review

\begin{tabular}{|c|c|c|c|c|c|c|c|c|c|c|c|c|c|}
\hline & Bunker [39] & $\begin{array}{l}\text { Carbone } \\
\text { et al. [31] }\end{array}$ & $\begin{array}{l}\text { Carrillon } \\
\text { et al. [32] }\end{array}$ & $\begin{array}{l}\text { Kilian et al. } \\
\text { [33] }\end{array}$ & Lho et al. [19] & Li et al. [34] & $\begin{array}{l}\text { Manton } \\
\text { et al. [35] }\end{array}$ & $\begin{array}{l}\text { Neviaser } \\
{[40]}\end{array}$ & $\begin{array}{l}\text { Sofka et al. } \\
\text { [14] }\end{array}$ & $\begin{array}{l}\text { Song } \\
\text { et al. [36] }\end{array}$ & $\begin{array}{l}\text { Uhthoff \& } \\
\text { Boileau [41] }\end{array}$ & $\begin{array}{l}\text { Xu et al. } \\
\text { [37] }\end{array}$ & $\begin{array}{l}\text { Zhao et al. } \\
\text { [38] }\end{array}$ \\
\hline $\begin{array}{l}\text { 1. Did the study } \\
\text { address a clearly } \\
\text { focused issue? }\end{array}$ & Yes & Yes & Yes & Yes & Yes & Yes & Yes & Yes & Yes & Yes & Yes & Yes & Yes \\
\hline $\begin{array}{l}\text { 2. Did the authors } \\
\text { use an appropriate } \\
\text { method to answer } \\
\text { their question? }\end{array}$ & $\begin{array}{l}\text { Yes } \\
\text { Arthroscopy } \\
\text { and Open } \\
\text { Release }\end{array}$ & $\begin{array}{l}\text { Yes } \\
\text { MRI - No } \\
\text { comment } \\
\text { on contrast }\end{array}$ & $\begin{array}{l}\text { Yes } \\
\text { MRI - } \\
\text { Contrast }\end{array}$ & $\begin{array}{l}\text { Yes } \\
\text { Arthroscopy }\end{array}$ & $\begin{array}{l}\text { Yes } \\
\text { Arthroscopy }\end{array}$ & $\begin{array}{l}\text { Yes } \\
\text { MRI - No } \\
\text { comment } \\
\text { on contrast }\end{array}$ & $\begin{array}{l}\text { Yes } \\
\text { Direct MRA }\end{array}$ & $\begin{array}{l}\text { Yes } \\
\text { Arthrography }\end{array}$ & $\begin{array}{l}\text { Yes } \\
\text { MRI - No } \\
\text { Comment } \\
\text { On } \\
\text { Contrast }\end{array}$ & $\begin{array}{l}\text { Yes } \\
\text { Indirect } \\
\text { MRI }\end{array}$ & $\begin{array}{l}\text { Yes } \\
\text { Arthroscopy }\end{array}$ & $\begin{array}{l}\text { Yes } \\
\text { Arthroscopy }\end{array}$ & $\begin{array}{l}\text { Yes } \\
\text { MRI- No } \\
\text { Comment } \\
\text { On Contrast }\end{array}$ \\
\hline $\begin{array}{l}\text { 3. Were the cases } \\
\text { recruited in an } \\
\text { acceptable way? }\end{array}$ & $\begin{array}{l}\mathrm{No} \\
\text { SoC } \\
N=35\end{array}$ & $\begin{array}{l}\text { Yes } \\
\text { SoC } \\
N=50\end{array}$ & $\begin{array}{l}\text { Yes } \\
\text { SoC } \\
N=25\end{array}$ & $\begin{array}{l}\text { No } \\
\text { SoC } \\
N=6\end{array}$ & $\begin{array}{l}\text { No } \\
\text { SoC } \\
N=17\end{array}$ & $\begin{array}{l}\text { Yes } \\
\text { SoC } \\
N=72\end{array}$ & $\begin{array}{l}\text { No } \\
\text { SoC } \\
N=9\end{array}$ & $\begin{array}{l}\text { No } \\
\text { SoC } \\
N=1\end{array}$ & $\begin{array}{l}\text { Yes } \\
\text { SoC } \\
N=47\end{array}$ & $\begin{array}{l}\text { Yes } \\
\text { SoC } \\
N=35\end{array}$ & $\begin{array}{l}\text { No } \\
\text { SoC } \\
N=4\end{array}$ & $\begin{array}{l}\text { Can't Tell } \\
N=8\end{array}$ & $\begin{array}{l}\text { Can't Tell } \\
N=60\end{array}$ \\
\hline $\begin{array}{l}\text { 4. Were the } \\
\text { controls selected } \\
\text { in an acceptable } \\
\text { way? }\end{array}$ & $\begin{array}{l}\text { No } \\
\text { No Control } \\
\text { Group }\end{array}$ & $\begin{array}{l}\text { Yes } \\
50 \text { Cuff Tear } \\
65 \text { Control }\end{array}$ & $\begin{array}{l}\text { No } \\
\text { No } \\
\text { Control } \\
\text { Group }\end{array}$ & $\begin{array}{l}\text { Yes } \\
6 \text { Control }\end{array}$ & $\begin{array}{l}\text { Yes } \\
7 \text { Control }\end{array}$ & $\begin{array}{l}\text { Yes } \\
120 \text { controls }\end{array}$ & $\begin{array}{l}\text { Yes } \\
19 \text { Control }\end{array}$ & $\begin{array}{l}\text { No } \\
\text { No Control } \\
\text { Group }\end{array}$ & $\begin{array}{l}\text { No } \\
\text { No } \\
\text { Control } \\
\text { Group }\end{array}$ & $\begin{array}{l}\text { Yes } \\
45 \\
\text { Control }\end{array}$ & $\begin{array}{l}\text { No } \\
\text { No Control } \\
\text { Group }\end{array}$ & $\begin{array}{l}\text { Can't Tell } \\
10 \text { Control }\end{array}$ & $\begin{array}{l}\text { Can't Tell } \\
60 \text { Control }\end{array}$ \\
\hline $\begin{array}{l}\text { 6. (a) What } \\
\text { confounding } \\
\text { factors have the } \\
\text { authors accounted } \\
\text { for? }\end{array}$ & $\begin{array}{l}\text { None } \\
\text { Recorded }\end{array}$ & $\begin{array}{l}\text { Gender } \\
\text { Age } \\
\text { Duration of } \\
\text { symptoms } \\
\text { Stage of } \\
\text { condition } \\
\text { Previous Mx }\end{array}$ & $\begin{array}{l}\text { Gender } \\
\text { Age } \\
\text { Duration } \\
\text { of } \\
\text { symptoms }\end{array}$ & $\begin{array}{l}\text { Stage of } \\
\text { condition }\end{array}$ & $\begin{array}{l}\text { Comorbidities } \\
\text { Previous Mx }\end{array}$ & $\begin{array}{l}\text { Gender } \\
\text { Age } \\
\text { Duration of } \\
\text { symptoms } \\
\text { Previous Mx } \\
\text { Comorbidity }\end{array}$ & $\begin{array}{l}\text { Gender } \\
\text { Age } \\
\text { Previous } \\
\text { Mx }\end{array}$ & $\begin{array}{l}\text { None } \\
\text { Recorded }\end{array}$ & $\begin{array}{l}\text { Gender } \\
\text { Age } \\
\text { Stage of } \\
\text { condition } \\
\text { Symptom } \\
\text { duration }\end{array}$ & $\begin{array}{l}\text { Gender } \\
\text { Age }\end{array}$ & $\begin{array}{l}\text { Gender } \\
\text { Age } \\
\text { Comorbidity } \\
\text { Duration of } \\
\text { symptoms }\end{array}$ & $\begin{array}{l}\text { Gender } \\
\text { Age } \\
\text { Comorbidity } \\
\text { Duration Of } \\
\text { Symptoms }\end{array}$ & $\begin{array}{l}\text { Gender } \\
\text { Age } \\
\text { Comorbidity } \\
\text { Ethnicity } \\
\text { Duration of } \\
\text { Symptoms }\end{array}$ \\
\hline $\begin{array}{l}\text { (b) Have the } \\
\text { authors taken } \\
\text { account of the } \\
\text { potential } \\
\text { confounding } \\
\text { factors in the } \\
\text { design and/or in } \\
\text { their analysis? }\end{array}$ & No & $\begin{array}{l}\text { Yes } \\
\text { Age } \\
\text { Comparable } \\
\text { Groups - Fs } \\
\text { \& Rc Tear }\end{array}$ & No & $\begin{array}{l}\text { Yes } \\
\text { Stage of } \\
\text { condition } \\
\text { and Sample }\end{array}$ & No & $\begin{array}{l}\text { Yes } \\
\text { Gender } \\
\text { affect }\end{array}$ & $\begin{array}{l}\text { Yes } \\
\text { Comorbidity } \\
\text { Different } \\
\text { treatment } \\
\text { of Control } \\
\text { Group/ } \\
\text { "Normals" }\end{array}$ & No & Yes & No & No & No & Yes \\
\hline $\begin{array}{l}\text { 7. Can the results } \\
\text { be applied to the } \\
\text { local population? }\end{array}$ & Can't Tell & $\begin{array}{l}\text { No } \\
\text { Diagnostic } \\
\text { Test } \\
\text { described } \\
\text { awaiting } \\
\text { validation }\end{array}$ & Yes & Can't Tell & No & Yes & No & No & Yes & Can't Tell & No & Can't Tell & Yes \\
\hline $\begin{array}{l}\text { 8. Do the results of } \\
\text { this study fit with } \\
\text { other available } \\
\text { evidence? }\end{array}$ & Can't Tell & Yes & Yes & No & Yes & Yes & No & Can't Tell & Yes & Yes & Yes & Can't Tell & Yes \\
\hline Overall risk of bias & High & Low & Moderate & Moderate & Moderate & Low & Mod & High & Low & Mod & Moderate & Moderate & Low \\
\hline
\end{tabular}


Table 5 Inter-operative observations and histological findings

\begin{tabular}{|c|c|c|c|c|}
\hline & & $\begin{array}{l}\text { Bunker [39] } \\
\text { Arthroscopy } \\
+/- \text { open release } \\
N=35\end{array}$ & $\begin{array}{l}\text { Uhthoff and Boileau [41] } \\
\text { Arthroscopy } \\
N=4\end{array}$ & $\begin{array}{l}\text { Xu et al. [37] } \\
\text { Arthroscopy } \\
N=8\end{array}$ \\
\hline \multirow[t]{2}{*}{ Rotator interval } & Appearance & Nodular thickening & No signs of inflammation & ---- \\
\hline & Histology & $\begin{array}{l}\uparrow \text { Fibroplasia } \\
\uparrow \text { Cellularity } \\
\uparrow \text { Vascularity }\end{array}$ & $\uparrow$ Fibroplasia & --- \\
\hline \multirow{2}{*}{$\begin{array}{l}\text { Coraco-humeral } \\
\text { ligament }\end{array}$} & Appearance & --- & No signs of inflammation & --- \\
\hline & Histology & --- & $\begin{array}{l}\uparrow \text { Fibroplasia } \\
\uparrow \text { Vascularity }\end{array}$ & --- \\
\hline \multirow[t]{2}{*}{ Inferior glenohumeral ligament } & Appearance & --- & No signs of inflammation & ---- \\
\hline & Histology & ---- & ---- & ---- \\
\hline \multirow[t]{2}{*}{ Joint capsule } & Appearance & Fibrous contracture in Rl area & $\begin{array}{l}\text { Posterosuperior: } \\
\text { No signs of inflammation } \\
\text { Inferior: } \\
\text { No signs of inflammation }\end{array}$ & $\begin{array}{l}\text { Above subscapularis tendon: } \\
\text { Thickened }\end{array}$ \\
\hline & Histology & $\uparrow$ Vascularity & $\begin{array}{l}\uparrow \text { Fibroplasia } \\
\uparrow \text { Vascularity }\end{array}$ & $\begin{array}{l}\uparrow \text { Fibroplasia } \\
\uparrow \text { Vascularity } \\
\text { Neoangiogenesis }\end{array}$ \\
\hline \multirow[t]{2}{*}{ Synovium } & Appearance & $\begin{array}{l}\text { Between subscapularis bursa and Rl: } \\
4 / 35 \text { Scarred. }\end{array}$ & $\begin{array}{l}\text { Rl: } \\
\text { Villous } \\
\text { CHL: } \\
\text { No villi } \\
\text { Posterosuperior: } \\
\text { Very villous } \\
\text { Inferior: } \\
\text { No villi } \\
\text { AF: } \\
\text { Very villous }\end{array}$ & --- \\
\hline & Histology & $\begin{array}{l}31 / 35 \text { Abnormal villous fronding. } \\
31 / 35 \uparrow \text { Vascularity }\end{array}$ & $\begin{array}{l}\text { Rl: } \\
\uparrow \text { Vascularity } \\
\text { Posterosuperior: } \\
\uparrow \text { Vascularity } \\
A F \text { : } \\
\uparrow \text { Vascularity }\end{array}$ & ---- \\
\hline \multirow[t]{2}{*}{ Subscapularis bursa } & Appearance & "Consistent abnormalities" & --- & --- \\
\hline & Histology & --- & --- & --- \\
\hline \multirow[t]{2}{*}{ Axillary fold } & Appearance & ---- & No signs of inflammation. & ---- \\
\hline & Histology & --- & $\uparrow$ Vascularity & --- \\
\hline
\end{tabular}

$\mathrm{N}$ (sample size), $\uparrow$ (increased), $\downarrow$ (decreased) CHL (coracohumeral ligament), RI (rotator interval), AF (axillary fold), -- (no findings or observations recorded)

evaluates gene expression through the presence of individual cells types, whereas, ICC indicates which proteins those cells are producing [52]. Although they had a relatively small number of participants $(N=4)$ Uhthoff and Boileau [41] conducted a comprehensive study to determine if fibroplasia affects all structures equally. Samples were taken anteriorly, posteriorly, superiorly and inferiorly around the shoulder joint. All structures demonstrated fibroplasia, however, vimentin was strongly expressed anteriorly but was absent in the posterior capsule, leading the authors to suggest that fibroplasia and contracture may be different processes. Their cohort consisted of 4 female subjects with no information pertaining to stage of the condition.
To reduce confounding variables the direct local introduction of medication into the joint was an exclusion criteria for the current review. All patients had failed conservative management; but no studies specified what this included. Common conservative management strategies for FS include oral analgesics and NSAIDs [53]. Therefore, the systemic effects of oral medications should be considered. Evidence in both bone and tendon literature suggests that ibuprofen reduces tensile strength, collagen fibre organisation and fibroblastic proliferation [54]. Almekinders et al. [55] conducted an in-vitro study of the effects of indomethacin on injured human tendon tissue. They reported diminished levels of fibroblast DNA synthesis in the groups treated with 
Table 6 Molecular findings

\begin{tabular}{|c|c|c|c|c|c|c|}
\hline & & Bunker [39] & Kilian et al. [33] & Lho et al. [19] & Uhthoff and Boileau [41] & Xu et al. [37] \\
\hline \multirow[t]{4}{*}{ Techniques used } & $\mathrm{IHC}$ & & $x$ & $x$ & $x$ & $x$ \\
\hline & ICC & $x$ & & & & \\
\hline & RTPCR & & $x$ & $x$ & & \\
\hline & ELISA & & & $x$ & & \\
\hline \multirow[t]{2}{*}{ Matrix components } & Fibroblasts & $\uparrow$ & $\downarrow$ & & $\uparrow$ & \\
\hline & Myofibroblasts & $\uparrow$ & $\downarrow$ & & & \\
\hline \multirow[t]{4}{*}{ Cytokines } & $\mathrm{IL}-1 \mathrm{a}$ & & & $\uparrow$ & & \\
\hline & $\mathrm{IL}-1 \beta$ & & & $\uparrow$ & & \\
\hline & IL-6 & & & $\uparrow$ & & \\
\hline & TNF-a & & & $\uparrow$ & & \\
\hline \multirow[t]{2}{*}{ Immune factors } & Leukocytes & $\downarrow$ & & & & \\
\hline & Macrophages & $\downarrow$ & & & & \\
\hline \multirow[t]{3}{*}{ Neuronal factors } & PGP9.5 & & & & & $\uparrow$ \\
\hline & GAP43 & & & & & $\uparrow$ \\
\hline & P75 & & & & & $\uparrow$ \\
\hline Vascular factors & CD34 & & & & & $\uparrow$ \\
\hline \multirow[t]{2}{*}{ Enzymes } & $\operatorname{cox} 1$ & & & $\uparrow$ & & \\
\hline & $\operatorname{cox} 2$ & & & $\uparrow$ & & \\
\hline
\end{tabular}

$\uparrow$ (increased), $\downarrow$ (decreased), IHC (immunohistochemistry analysis), ICC (immunocytochemical examination), RTPCR (real time reverse transcription-polymerase chain reaction), ELISA (enzyme-linked immunosorbent assay), IL-1a (interleukin 1 alpha), IL-1 $\beta$ (interleukin 1 beta), IL-6 (interleukin 6), TNF-a (tumour necrosis factor alpha), PGP9.5 (polyclonal rabbit antiprotein gene product 9.5), GAP43 (monoclonal mouse antigrowth-associated protein 43 ), P75 (nerve growth factor receptor p75), CD34 (monoclonal mouse antihuman CD34), COX1 (cyclooxygenase 1), COX 2 (cyclooxygenase 2)

indomethacin compared to control. It is important to acknowledge that levels of reported fibroplasia may have been influenced by pharmaceutical preparations potentially prescribed to treat the symptoms.

\section{Inflammation and immune modulation}

Cyclooxygenases play an important role in inflammation and the collagen catabolic process within peripheral tissues [53]. Lho et al. [19] used RTPCR and IHC and reported increased expression of COX1 in the endothelial cells and stroma of the joint capsule and increased expression of COX2 in the capsule and subacromial bursa of the FS group. Furthermore, levels of IL-1 $\alpha$, IL- $\beta$, IL6 and TNF- $\alpha$ also differed between the capsule, bursa and joint fluid. Interleukin and TNF- $\alpha$ are pro-inflammatory cytokines; released from immune cells such as macrophages [54]. This may imply that high numbers of these cells may be present in the joint [56]. Bunker [39] reported low numbers of macrophages and leukocytes in the RI. This variation may be reflective of differing pathological processes between structures and/or that the biopsies were taken from different stages of disease, and possibly different diagnostic criteria. Neither Bunker [39] nor Lho et al. [19] provided sufficient background data regarding their participants to explore this. Furthermore, no comparable studies were included in this SR which again reveals a gap in the evidence base that is worthy of exploration.

\section{Neuronal and vascular factors}

Pain is associated with FS [3]. Hand et al. [6] conducted a longitudinal study of 223 patients with frozen shoulder with a mean follow up time of 4.4 years (range 2 to 20 years), with $41 \%$ of the patient's reporting mild to moderate pain and $6 \%$ reported severe pain. To date, few studies have investigated the causes of pain experienced by patients with FS [57]. In this review, $\mathrm{Xu}$ et al. [37] investigated neuronal components associated with PFS, reporting elevated levels of several immunoreactive neuronal proteins (GAP43, PGP9.5 and P75) in the anterosuperior joint capsule, close to small blood vessels or within fibroblastic tissue. These findings confirm the presence of mature and regenerating nerve fibres in the anterosuperior capsule and may explain the severe pain experienced by sufferers of the condition in the early stages (less than six months). Increased vascularity was a common feature identified in the histology studies; particularly located in the anterosuperior structures but absent in the inferior structures (with the exception of the axillary fold (AF)). This is consistent with the literature where hypervascularity and angiogenesis have been reported as potential sources of pain due to their 
association with neovessels [58, 59]. Xu et al. [37] reported stronger expression of CD34 (a haematopoietic cell marker) in the superior joint capsule of the FS group compared RC tears, as a control population. Limited conclusions may be drawn from this study because of the small sample size $(n=8)$. Ryu et al. [58] investigated FS in a diabetic cohort and reported CD34 to be strongly expressed. However, caution must be taken when extrapolating these results as the patient's had received corticosteroid injections. A recent study by Okuno et al. [59] reported that arterial embolization of neovessels in the RI provided rapid relief of pain in their FS group. Limited knowledge exists regarding the pain mechanisms involved with FS [60]. This SR has provided some insight into possible causes. This knowledge has great significance for clinicians as pain is often the dominant complaint in patients with FS. The literature has suggested that the condition may manifest differently between individuals. A greater understanding would greatly assist clinicians to effectively manage this symptom in their patients. It is clear further research is required.

\section{Limitations}

It is acknowledged that this systematic review has a number of limitations. These are reviewed in the following section.

\section{Searches}

Only English language publications were included in this review so the introduction of language bias cannot be ruled out. Studies where an English translation could not be sourced were identified during abstract analysis. One reviewer (VR) identified eighteen studies where the full text English article could not be sourced. The second reviewer (HB) identified six of those eighteen. All eighteen studies were excluded. The evidence surrounding language bias is conflicting [30], and it is not known how these non-English publications may have influenced the findings of the current review.

No date restriction was applied to the studies so that all available studies could be identified and included in this systematic review, believed to be the first of this type, in this condition. MRI was first introduced into healthcare in the 1980's, and over time image quality has advanced substantially [61]. The implication of this is that the reported imaging findings from the earlier studies $[32,35]$ may lack the sensitivity of those in later studies [31]. This also may have influenced the findings and contributed to reported discrepancies.

\section{Inclusion and exclusion criteria}

The aim of the review was to investigate the intra and peri-articular pathophysiology of the glenohumeral joint in people diagnosed with primary idiopathic frozen shoulder. Only studies specifying primary frozen shoulder were included as it was not possible to separate the findings from investigations that included both primary and secondary frozen shoulders. This meant that primary frozen shoulder findings may have been missed by excluding studies that incorporated both. The decision to only include samples from people diagnosed with primary FS hopefully generated more homogenised data.

Direct injection of medication into the joint was an exclusion criteria in this review to reduce the potential confounding influencing this may have had on the findings. However, there may be other sources of confounding which might have affected the findings of this review. All patients included in the review had had failed conservative management but none of the studies specified what this included. Common conservative management strategies for frozen shoulder include oral analgesics and NSAIDs [62] and potentially, the systemic effects of such oral medications may have also influenced findings.

\section{Widespread variation}

The main limitation of this review relates to the included studies. Variations in diagnosis, methods of sample selection, timing of sampling, and confounding variables such as use of oral medications, all may have influenced the reported findings and the conclusions of this review. Meta-analysis was not considered due to the considerable and widespread variance within the included studies [30].

\section{Risk of bias}

The majority of studies $(n=7)$ were identified as having a moderate risk of bias, with two studies assessed of being at high risk of bias and the remaining four rated as low risk of bias. Study characteristics were poorly reported. There are three possible concerns for this review. The first is, as previously mentioned, a risk of bias tool specifically for use in pathophysiology reviews was not found, meaning there may be specific domains relevant for this type of review which have not been appraised or discussed. The second is that, with only a minority of studies being assessed as low risk of bias, the findings of this review may contain systematic bias [30]. Metaanalyses were not included in this review: it is accepted that meta-analyses of studies that are at risk of bias may be seriously misleading since meta-analysis may simply compound the errors, thus producing an erroneous results which may be interpreted as having more credibility [30]. The third concern is that the ACROBAT-NRSI tool, as a recent development to meet the need for a tool to assess risk of bias in non-randomised studies, has yet to be widely used or evaluated. Further research on the performance of the tool in the future may influence the 
findings of this review or enable the findings to be placed more appropriately in context.

\section{Conclusions}

This systematic review is the first review to synthesise imaging and histological studies to examine the pathophysiology associated with primary frozen shoulder. The review highlights the role of the anterior shoulder structures in primary frozen shoulder, but there is a lack of available evidence considered at low risk of bias to inform understanding of the pathophysiology of the primary frozen shoulder condition. Consensus regarding inclusion criteria (and the interpretation of the Codman classification criteria) is first required for future research to promote studies providing comparable findings. Following this, further studies that identify findings at clearly defined stages of the condition are required to improve the understanding of the disease continuum. Improved understanding may then inform management specific to each stage of this painful, disabling common condition so that it is no longer difficult to define, treat or explain.

\section{Abbreviations}

ACROBAT-NRSI, a cochrane risk of bias assessment tool for non-randomized studies of interventions; AF, axillary fold; AMED, allied and complementary medicine database; $\mathrm{BNI}$, British nursing index; $\mathrm{CHL}$, coracohumeral ligament; CINAHL, cumulative index to nursing and allied health literature; FS, frozen shoulder; ICC, immunocytochemistry; IHC, immunohistochemistry; IL, interleukin; LHB, long head of biceps; MRA, magnetic resonance angiogram; MRI, magnetic resonance imaging; mRNA, messenger RNA; MUA, manipulation under anaesthetic; NSAIDs, non-steroidal anti-inflammatory drugs; PFS, primary frozen shoulder; PICO, population, intervention, comparator and outcome; PRISMA, preferred reporting items for systematic reviews and meta-analyses; QUADAS-2, quality assessment of diagnostic accuracy studies; RTPCR, reverse transcription polymerase chain reaction; TNF, tumour necrosis factor

\section{Acknowledgements}

This review was undertaken in partial fulfilment of an MSc Advanced Physiotherapy for HB and MSc Advanced Neuro-musculoskeletal Physiotherapy for VR undertaken at the Department of Allied Health Professions and Midwifery, School of Health and Social Work, University of Hertfordshire, UK. This project was supported by an MACP (Musculoskeletal Association of Chartered Physiotherapists) student research award (2015).

Mr Marco Isetta, Library and Knowledge Services Manager, Central and North West London NHS Foundation Trust.

\section{Funding}

The Health Foundation (http://www.health.org.uk) is gratefully acknowledged for providing funding to support this project.

\section{Availability of data and materials}

All the data supporting the findings of this Systematic Review are contained within the manuscript

\section{Authors' contributions}

HB: Conceived the study, identified the research question, identified the inclusion and exclusion criteria, completed a systematic literature search, identified articles for abstract analysis, completed abstract analysis, completed data extraction and contributed to writing up the findings. VR: Conceived the study, identified the research question, identified the inclusion and exclusion criteria, completed a systematic literature search, identified articles for abstract analysis, completed abstract analysis, completed data extraction and contributed to writing up the findings. CML:
Contributed to the design of this review and its processes, and contributed to the writing up, revising and editing of this manuscript. JL: Conceived the study, contributed to the identification of the research question and the inclusion and exclusion criteria, acted as a third reviewer and contributed to write up of the findings and editing the manuscript. All authors read and approved the final manuscript.

\section{Competing interests}

The authors declare that they have no competing interests.

\section{Consent for publication}

Not applicable.

Ethics approval and consent to participate

Not applicable given that this is a systematic review.

\section{Author details}

${ }^{1}$ Central North West London NHS Foundation Trust, London, UK. ${ }^{2}$ Royal National Orthopaedic Hospital NHS Trust, London, UK. ${ }^{3}$ Department of Allied Health Professions and Midwifery, School of Health and Social Work, University of Hertfordshire, Hatfield, UK. ${ }^{4}$ Central London Community Healthcare NHS Trust, London, UK.

Received: 30 January 2016 Accepted: 29 July 2016

Published online: 15 August 2016

References

1. Kelley MJ, Shaffer MA, Kuhn JE, Michener LA, Seitz AL, Uhl TL, et al. Shoulder pain and mobility deficits: adhesive capsulitis. J Orthop Sports Phys Ther 2013;43(5):A1-31. doi:10.2519/jospt.2013.0302. 10.2519/jospt.2013.43.1.A1.

2. Lewis J. Frozen shoulder contracture syndrome - Aetiology, diagnosis and management. Man Ther. 2015;20(1):2-9. doi:10.1016/j.math.2014.07.006.

3. Jones S, Hanchard N, Hamilton S, Rangan A. A qualitative study of patients' perceptions and priorities when living with primary frozen shoulder. BMJ open. 2013:3(9):e003452. doi:10.1136/bmjopen-2013-003452.

4. Reeves B. The natural history of the frozen shoulder syndrome. Scand J Rheumatol. 1975:4(4):193-6.

5. Shaffer B, Tibone JE, Kerlan RK. Frozen shoulder. A long-term follow-up. J Bone Joint Surg. 1992;74(5):738-46.

6. Hand C, Clipsham K, Rees JL, Carr AJ, et al. Long-term outcome of frozen shoulder. J Shoulder Elbow Surgery. 2008;17(2):231-6. doi:10.1016/j.jse.2007. 05.009.

7. Urwin M, Symmons D, Allison T, Brammah T, Busby H, Roxby M, et al. Estimating the burden of musculoskeletal disorders in the community: the comparative prevalence of symptoms at different anatomical sites, and the relation to social deprivation. Ann Rheum Dis. 1998:57(11):649-55.

8. Codman E. The Shoulder: Rupture of the supraspinatus tendon and other lesions in or about the subacromial bursa. Boston: Thomas Todd Company; 1934

9. Lundberg BJ. The frozen shoulder. Acta Orthop Scand Suppl. 1969;1 19:1-59.

10. Zuckerman JD, Coumo F, Rokito S. Definition and classification of frozen shoulder: A consensus approach. Journal of Shoulder and Elbow Surgery. 1994;3(S72).

11. Hand GC, Athanasou NA, Matthews T, Carr AJ. The pathology of frozen shoulder. J Bone Joint Surg. 2007;89(7):928-32. doi:10.1302/0301-620X. 89B7.19097.

12. Zuckerman JD, Rokito A, et al. Frozen shoulder: a consensus definition. Shoulder Elbow Surgery. 2011;20(2):322-5. doi:10.1016/j.jse.2010.07.008.

13. Milgrom C, Novack V, Weil Y, Jaber S, Radeva-Petrova DR, Finestone A. Risk factors for idiopathic frozen shoulder. Israel Med Assoc J. 2008;10(5):361-4

14. Sofka CM, Ciavarra GA, Hannafin JA, Cordasco FA, Potter HG. Magnetic resonance imaging of adhesive capsulitis: correlation with clinical staging. HSS J. 2008:4(2):164-9. doi:10.1007/s11420-008-9088-1.

15. Tamai K, Akutsu M, Yano Y. Primary frozen shoulder: brief review of pathology and imaging abnormalities. J Orthopaedic Sci. 2014;19(1):1-5. doi:10.1007/s00776-013-0495-x

16. Duplay S. De la periarthrite scapulo-humerale. Rev frat $d$ trav de med. 1896:53:226. 
17. Neviaser J. Adhesive capsulitis of the shoulder. A study of the pathological findings in periarthritis of the shoulder. J Bone Joint Surgery (Am). 1945;27(2):211-22.

18. Gondim Teixeira PA, Balaj C, Chanson A, Lecocq S, Louis M, Blum A. Adhesive capsulitis of the shoulder: value of inferior glenohumeral ligament signal changes on T2-weighted fat-saturated images. AJR Am J Roentgenol. 2012;198(6):W589-96. doi:10.2214/AJR.11.7453.

19. Lho YM, Ha E, Cho CH, Song KS, Min BW, Bae KC, et al. Inflammatory cytokines are overexpressed in the subacromial bursa of frozen shoulder. J Shoulder Elbow Surgery. 2013;22(5):666-72. doi:10.1016/j.jse.2012.06.014.

20. Bunker TD, Reilly J, Baird KS, Hamblen DL. Expression of growth factors, cytokines and matrix metalloproteinases in frozen shoulder. J Bone Joint Surg. 2000;82(5):768-73.

21. Bunker TD, Anthony PP. The pathology of frozen shoulder. A Dupuytren-like disease. J Bone Joint Surg. 1995;77(5):677-83.

22. Omari A, Bunker TD, et al. Open surgical release for frozen shoulder: surgical findings and results of the release. J Shoulder Elbow Surgery. 2001;10(4):353-7.

23. Kanbe K, Inoue K, Inoue Y, Chen Q. Inducement of mitogen-activated protein kinases in frozen shoulders. J Orthopaedic Sci. 2009;14(1):56-61. doi:10.1007/s00776-008-1295-6.

24. Moher D, Liberati A, Tetzlaff J, Altman DG. Preferred reporting items for systematic reviews and meta-analyses: the PRISMA statement. BMJ. 2009; 339:b2535. doi:10.1136/bmj.b2535.

25. Sackett D, Straus S, Richardson W, Rosenberg W, Haynes R. Evidence-based medicine. How to teach and practice EBM. 2 ed. Edinburgh: Churchill Livingstone; 2000.

26. Dean BJ, Lostis E, Oakley T, Rombach I, Morrey ME, Carr AJ. The risks and benefits of glucocorticoid treatment for tendinopathy: a systematic review of the effects of local glucocorticoid on tendon. Semin Arthritis Rheum. 2014;43(4):570-6. doi:10.1016/j.semarthrit.2013.08.006

27. Favejee MM, Huisstede BM, Koes BW. Frozen shoulder: the effectiveness of conservative and surgical interventions-systematic review. Br J Sports Med. 2011;45(1):49-56. doi:10.1136/bjsm.2010.071431.

28. Loew M, Heichel TO, Lehner B, et al. Intraarticular lesions in primary frozen shoulder after manipulation under general anesthesia. J Shoulder Elbow Surgery. 2005;14(1):16-21. doi:10.1016/j.jse.2004.04.004.

29. UoYCfRa D. Systematic reviews: CRD's guidance for undertaking reviews in health care. York: York Publishing Services Ltd.; 2009.

30. Higgins JP. Cochrane handbook for systematic reviews of interventions (Vol. 5). Chichester: Wiley-Blackwell; 2008.

31. Carbone S, Napoli A, Gumina S. MRI of adhesive capsulitis of the shoulder: distension of the bursa in the superior subscapularis recess is a suggestive sign of the pathology. Eur J Radiol. 2014;83(2):345-8. doi:10.1016/j.ejrad. 2013.10.017.

32. Carrillon Y, Noel E, Fantino O, Perrin-Fayolle O, Tran-Minh VA. Magnetic resonance imaging findings in idiopathic adhesive capsulitis of the shoulder. Rev Rhum Engl Ed. 1999;66(4):201-6.

33. Kilian O, Pfeil U, Wenisch S, Heiss C, Kraus R, Schnettler R. Enhanced alpha 1 (I) mRNA expression in frozen shoulder and dupuytren tissue. Eur J Med Res. 2007;12(12):585-90.

34. Li JQ, Tang KL, Wang J, Li QY, Xu HT, Yang HF, et al. MRI findings for frozen shoulder evaluation: is the thickness of the coracohumeral ligament a valuable diagnostic tool? PLoS One. 2011;6(12):e28704. doi:10.1371/journal. pone.0028704

35. Manton GL, Schweitzer ME, Weishaupt D, Karasick D. Utility of MR arthrography in the diagnosis of adhesive capsulitis. Skeletal Radiol. 2001;30(6):326-30.

36. Song KD, Kwon JW, Yoon YC, Choi SH. Indirect MR arthrographic findings of adhesive capsulitis. AJR Am J Roentgenol. 2011;197(6):W1105-9. doi:10.2214/AJR.10.6099

37. Xu Y, Bonar F, Murrell GA, et al. Enhanced expression of neuronal proteins in idiopathic frozen shoulder. J Shoulder Elbow Surgery. 2012;21(10):1391-7. doi:10.1016/j.jse.2011.08.046.

38. Zhao W, Zheng X, Liu Y, Yang W, Amirbekian V, Diaz LE, et al. An MRI study of symptomatic adhesive capsulitis. PLoS One. 2012;7(10):e47277. doi:10.1371/journal.pone.0047277.

39. Bunker TD. Frozen shoulder: unravelling the enigma. Ann R Coll Surg Engl. 1997:79(3):210-3.

40. Neviaser JS. Arthrography of the shoulder joint: study of the findings in adhesive capsulitis of the shoulder. Study of the findings in adhesive capsulitis of the shoulder. J Bone Joint Surgery. 1962;44-A:1321-59.
41. Uhthoff HK, Boileau P. Primary frozen shoulder: global capsular stiffness versus localized contracture. Clin Orthop Relat Res. 2007:456:79-84. doi:10.1097/BLO.0b013e318030846d.

42. Xu Y, Bonar F, Murrell GA. Enhanced expression of neuronal proteins in idiopathic frozen shoulder. Journal of shoulder and elbow surgery / American Shoulder and Elbow Surgeons. 2011

43. Chundru U, Riley GM, Steinbach LS. Magnetic resonance arthrography. Radiol Clin North Am. 2009:47(3):471-94. doi:10.1016/j.rcl.2009.02.001.

44. Elentuck D, Palmer WE. Direct magnetic resonance arthrography. Eur Radiol. 2004;14(11):1956-67. doi:10.1007/s00330-004-2449-3.

45. Emig EW, Schweitzer ME, Karasick D, Lubowitz J. Adhesive capsulitis of the shoulder: MR diagnosis. AJR Am J Roentgenol. 1995;164(6):1457-9. doi:10.2214/ajr.164.6.7754892.

46. Kim KC, Rhee KJ, Shin HD, et al. Adhesive capsulitis of the shoulder: dimensions of the rotator interval measured with magnetic resonance arthrography. J Shoulder Elbow Surgery. 2009;18(3):437-42. doi:10.1016/j.jse. 2008.10.018.

47. Mengiardi B, Pfirrmann CW, Gerber C, Hodler J, Zanetti M. Frozen shoulder: MR arthrographic findings. Radiology. 2004;233(2):486-92. doi:10.1148/radiol. 2332031219.

48. Bergin D, Schweitzer ME. Indirect magnetic resonance arthrography. Skeletal Radiol. 2003;32(10):551-8. doi:10.1007/s00256-003-0669-2.

49. Ozaki J, Nakagawa Y, Sakurai G, Tamai S. Recalcitrant chronic adhesive capsulitis of the shoulder. Role of contracture of the coracohumeral ligament and rotator interval in pathogenesis and treatment. J Bone Joint Surgery. 1989;71(10):1511-5.

50. Rodeo SA, Hannafin JA, Tom J, Warren RF, Wickiewicz TL. Immunolocalization of cytokines and their receptors in adhesive capsulitis of the shoulder. J Orthopaedic Res. 1997;15(3):427-36. doi:10.1002/jor. 1100150316.

51. Smith SP, Devaraj VS, Bunker TD, et al. The association between frozen shoulder and Dupuytren's disease. J Shoulder Elbow Surgery. 2001:10(2):149-51.

52. Dean BJ, Franklin SL, Carr AJ. A systematic review of the histological and molecular changes in rotator cuff disease. Bone Joint Res. 2012;1(7):158-66. doi:10.1302/2046-3758.17.2000115.

53. Dyson M. Inflammation, wounds and wound healing. In: Shamley D, editor. Pathophysiology. Edinburgh: Elsevier; 2005. p. 3-15.

54. Shahriari S, Rezaei A, Jalalzadeh SM, Mani K, Zamani A. Effect of Ibuprofen on IL-1beta, TNF-alpha and PGE2 levels in periapical exudates: a double blinded clinical trial. Iran J Immunol. 2011;8(3):176-82. IJlv8i3A5.

55. Almekinders LC, Baynes AJ, Bracey LW. An in vitro investigation into the effects of repetitive motion and nonsteroidal antiinflammatory medication on human tendon fibroblasts. Am J Sports Med. 1995;23(1):119-23.

56. Shamley D. Diseases of the immune system. In: Shamley D, editor. Pathophysiology. Edinburgh: Elsevier; 2005. p. 3-15.

57. Ochiai N, Ohtori S, Kenmoku T, Yamazaki H, Ochiai S, Saisu T, et al. Sensory innervation of rat contracture shoulder model. J Shoulder Elbow Surgery. 2013;22(2):158-64. doi:10.1016/j.jse.2012.02.011.

58. Ryu JD, Kirpalani PA, Kim JM, Nam KH, Han CW, Han SH, et al. Expression of vascular endothelial growth factor and angiogenesis in the diabetic frozen shoulder. J Shoulder Elbow Surgery. 2006;15(6):679-85. doi:10.1016/j.jse.2006.01.002

59. Okuno Y, Oguro S, Iwamoto W, Miyamoto T, Ikegami $H$, Matsumura N, et al. Short-term results of transcatheter arterial embolization for abnormal neovessels in patients with adhesive capsulitis: a pilot study. J Shoulder Elbow Surgery. 2014;23(9):e199-206. doi:10.1016/j.jse.2013.12.014.

60. Dawson J, Shepperd S, Carr A. An overview of factors relevant to undertaking research and reviews on the effectiveness of treatment for frozen shoulder. Shoulder Elbow. 2010;2:232-7.

61. Sobol WT. Recent advances in MRI technology: Implications for image quality and patient safety. Saudi J Ophthalmol. 2012;26(4):393-9. doi:10.1016/j.sjopt.2012.07.005.

62. Hsu JE, Anakwenze OA, Warrender WJ, Abboud JA, et al. Current review of adhesive capsulitis. J Shoulder Elbow Surgery. 2011;20(3):502-14. doi:10.1016/j.jse.2010.08.023. 